Article

\title{
Antioxidant and Antigenotoxic Activities of the Brazilian Pine Araucaria angustifolia (Bert.) O. Kuntze
}

\author{
Márcia O. Souza ${ }^{1}$, Cátia S. Branco ${ }^{1}$, Juliane Sene ${ }^{1}$, Rafaela DallAgnol ${ }^{1}$, Fabiana Agostini ${ }^{2}$, \\ Sidnei Moura ${ }^{2}$ and Mirian Salvador ${ }^{1, *}$
}

1 Laboratory of Oxidative Stress and Antioxidants, Biotechnology Institute, University of Caxias do Sul, RS 95070560, Brazil; E-Mails: marciadenizesouza@gmail.com (M.O.S.); csbranc1@ucs.br (C.S.B); jssene@ucs.br (J.S.); rdallagnol@ucs.br (R.D.)

2 Laboratory of Biotechnology of Natural and Synthetics Products, Technology Department, Biotechnology Institute, University of Caxias do Sul, RS 95070560, Brazil;

E-Mails: fagosti1@ucs.br (F.A.); smsilva11@ucs.br (S.M.)

* Author to whom correspondence should be addressed; E-Mail: msalvado@ucs.br; Tel.: +55-54-3218-2105; Fax: +55-54-3218-2664.

Received: 12 November 2013; in revised form: 18 December 2013 / Accepted: 30 December 2013 / Published: 6 January 2014

\begin{abstract}
Polyphenols are natural products with recognized potential in drug discovery and development. We aimed to evaluate the polyphenolic profile of Araucaria angustifolia bracts, and their ability to scavenge reactive species. The antioxidant and antigenotoxic effects of $A$. angustifolia polyphenols in MRC5 human lung fibroblast cells were also explored. The total polyphenol extract of $A$. angustifolia was determined by the Folin-Ciocalteu reagent and the chemical composition was confirmed by HPLC. Reactive oxygen species' scavenging ability was investigated by the 2,2-diphenyl-1-picrylhydrazyl (DPPH) method and superoxide dismutase- and catalase-like activities. The protective effect of the extract in MRC5 cells was carried out by the 3-(4,5-dimethylthiazol-2-yl)-2,5diphenyltetrazolium bromide method and the determination of oxidative lipids, protein, and DNA (alkaline and enzymatic comet assay) damage. Total phenolic content of the A. angustifolia extract was $1586 \pm 14.53 \mathrm{mg}$ gallic acid equivalents $/ 100 \mathrm{~g}$ of bracts. Catechin, epicatechin, quercetin, and apigenin were the major polyphenols. The extract was able to scavenge DPPH radicals and exhibited potent superoxide dismutase and catalase-like activities. Moreover, A. angustifolia extract significantly protected MRC5 cells against $\mathrm{H}_{2} \mathrm{O}_{2}$-induced mortality and oxidative damage to lipids, proteins, and DNA. Therefore, A. angustifolia has potential as a source of bioactive chemical compounds.
\end{abstract}


Keywords: Araucaria angustifolia; polyphenols; antioxidant; antigenotoxicity; MRC5

\section{Introduction}

Plant secondary metabolites have contributed to the development of new active molecules used in therapeutics. The diversity of the plant kingdom represents an immense reservoir of structures with potential pharmacological value. Araucaria angustifolia (Bert.) O. Kuntze (Araucariaceae) is a native conifer of Southern Brazil, which is popularly known as "pinheiro-do-paraná" or "pinheiro-brasileiro". It is a dioecious species, which means it features male and female specimens that have their own distinct strobilus. The female strobilus consists of seeds (the edible part of A. angustifolia) and bracts, which are undeveloped seeds commonly discarded into the environment.

Different parts of $A$. angustifolia are used in Brazilian folk medicine. Infusions of bark are used to treat muscle strains and varices and the syrup produced from resin is used to treat respiratory tract infections. Moreover, infusions of leaves (needles) are used to treat scrofula, fatigue, and anemia [1,2].

Despite its traditional uses, few phytochemical and pharmacological studies have been performed from $A$. angustifolia. The dead bark of the tree has a high concentration of anthocyanins and proanthocyniadins, and presents antioxidant effects on liposomes and rat microsomes [3]. $A$. angustifolia needles contain proanthocyanidins and biflavonoids such as amentoflavone, mono- $O$ methylamentoflavone, di- $O$-methylamentoflavone, ginkgetin, tri- $O$-methylamentoflavone and tetra- $O$ methylamentoflavone [4,5]. It was shown that biflavonoids exhibit minor antiherpes activity and the proanthocyanidins seem to be mainly responsible for the antiviral activity of $A$. angustifolia needles [6]. The needles can also reduce lipoperoxidation and DNA damage in liposomal membranes [4] and in calf thymus cells [5]. The resin from A. angustifolia is rich in lignans and phenolic compounds, such as 4-hydroxybenzaldehyde, hydroquinone and $p$-coumaric acid [7]. The seed of this tree, named pinhão, is rich in lectins with anti-inflammatory and antibacterial activities [8].

In our previous study [9], we found that the aqueous extract of bracts from A. angustifolia presents antimutagenic activity and high levels of polyphenols. These bioactive compounds can act as reducing and/or scavengers agents, minimizing the generation of reactive species (RS) [10] implicated in protein, lipid, and nucleic acid damage [9]. Therefore, polyphenols could reduce the occurrence of several diseases associated with oxidative stress, such as cancer and cardiovascular and neurological diseases [11].

The present study aimed to evaluate the polyphenolic profile of $A$. angustifolia bracts and the ability of this extract to scavenge reactive species. In addition, the effects of A. angustifolia in human lung fibroblast cells (MRC5) were also studied.

\section{Experimental Section}

\subsection{Chemicals}

Dulbecco's modified eagle medium (DMEM), fetal bovine serum (FBS), trypsin-EDTA and penicillin-streptomycin were purchased from Gibco BRL (Grand Island, NY, USA). Thiobarbituric 
acid (TBA), trichloroacetic acid (TCA), dinitrophenylhydrazine (DNPH), 2,2-diphenyl-1-picrylhydrazyl (DPPH), hydrolyzed 1,1,3,3-tetramethoxypropane (TMP), catechin, epicatechin, quercetin, apigenin, 3-(4,5-dimethylthiazol-2-yl)-2,5-diphenyltetrazolium bromide (MTT), radio-immunoprecipitation assay (RIPA) buffer, and hydrogen peroxide $\left(\mathrm{H}_{2} \mathrm{O}_{2}\right)$ were obtained from Sigma-Aldrich (St. Louis, MO, USA). Low-melting point agarose and normal agarose were purchased from Invitrogen (Carlsbad, CA, USA). Formamidopyrimidine DNA glycosylase (FPG, $8.000 \mathrm{U} / \mathrm{mL}$ ) and endonuclease (Endo) III $(10.000 \mathrm{U} / \mathrm{mL})$ were purchased from New England BioLabs (Ipswich, MA, USA). HPLC solvents were from Mallinckrodt Baker Inc. (Phillipsburg, NJ, USA).

\subsection{Plant Material and Preparation of the Extract}

Pines of A. angustifolia were collected in Caxias do Sul, Rio Grande do Sul (latitude -29¹0'05", longitude $\left.-51^{\circ} 10^{\prime} 46^{\prime \prime}\right)$, Brazil, in 2011. Voucher specimens were identified by the herbarium of the University of Caxias do Sul, Rio Grande do Sul, Brazil (HUCS36536). Bracts were manually separated and mixed to obtain a pool, which was used to prepare the extract. Bracts were dried in incubator air oven at $37{ }^{\circ} \mathrm{C}$, milled (Tecnal model Willye TE-650) and mixed with distilled water (5\%, w/v). Extraction was done under reflux $\left(100{ }^{\circ} \mathrm{C}\right)$ for $15 \mathrm{~min}$, as described by Michelon et al. [9]. After cooling to $25^{\circ} \mathrm{C}$, the $A$. angustifolia extract (AAE) was filtered in Millipore equipment (pore size, $0.45 \mu \mathrm{m}$; catalog number SFGS 047LS, Millipore Corp., São Paulo, Brazil), lyophilized (LIOBRAS model L-101), and stored in the dark. Before each assay, the lyophilized powder was resuspended in water.

\subsection{Determination of Total Phenolic Content and Major Compounds}

Total phenolic content of the extract was measured by using the Folin-Ciocalteu colorimetric method, according to Singleton and Rossi [12], with modifications. Briefly, the lyophilized extract $(5 \%$, w/v) was mixed with $400 \mu \mathrm{L}$ of sodium carbonate $(7.5 \%$, w/v) and $500 \mu \mathrm{L}$ of Folin-Ciocalteu reagent. After $30 \mathrm{~min}$ in the dark, the absorbance was measured at $765 \mathrm{~nm}$ in a spectrophotometer (UV-1700 spectrophotometer, Shimadzu, Kyoto, Japan). Phenolic content of the extract was expressed as $\mathrm{mg}$ of gallic acid equivalents (GAE) per $100 \mathrm{~g}$ of bracts.

Identification and quantification of the major compounds in AAE was performed by HPLC analysis, using an HP 1100 system equipped with a UV/VIS detector (Santa Clara, CA, USA). Compound separation was performed with a $5 \mu \mathrm{m}$ Li-Chrospher RP18 column $(250 \mathrm{~mm} \times 4 \mathrm{~mm})$ at a flow rate of $1 \mathrm{~mL} / \mathrm{min}$. The extract was filtered on a Millipore membrane $(0.45 \mu \mathrm{m})$ and $20 \mu \mathrm{L}$ injected into the device. Analysis of flavonoids was performed using a binary solvent system consisting of methanol (solvent A) and a water/acetic acid mixture (100/2) (solvent B) as the mobile phase unit. Gradient conditions were: 15\% solvent $\mathrm{A}$ and $85 \% \mathrm{~B}(0-30 \mathrm{~min}), 40 \%$ solvent $\mathrm{A}$ and $60 \% \mathrm{~B}$ (30-40 min), 75\% solvent $A$ and $25 \%$ B (40-45 min), and $85 \%$ solvent A and $15 \%$ B (45-50 min). Flavonoids were monitored by UV absorbance at $350 \mathrm{~nm}$. All chromatographic procedures were performed at $25{ }^{\circ} \mathrm{C}$. To quantify the main tannins, the extract was eluted at $1 \mathrm{~mL} / \mathrm{min}(20 \mu \mathrm{L}$ injection volume) using an isocratic mobile phase $90 \%$ acidic water (5\% acetic acid) and $10 \%$ acidic methanol (5\% acetic acid). The tannins were monitored by UV absorbance at $280 \mathrm{~nm}$ at $45 \mathrm{~min}$. The concentrations of flavonoids (quercetin and apigenin) and tannins (catechin and epicatechin) were 
estimated from standard curves obtained by the analysis of various doses of standard compounds (all from Sigma-Aldrich). Results are expressed in $\mathrm{mg} / 100 \mathrm{~g}$ bracts.

\subsection{Radical Scavenging Activity, Superoxide Dismutase-, and Catalase-Like Activities}

Antioxidant activity of the AAE was measured through the ability of the extract to donate electrons to the stable radical 2,2-diphenyl-1-picrylhydrazyl (DPPH) [13]. Briefly, the lyophilized powder was diluted to different concentrations $(0.05,0.1,0.15,0.2,0.25$ and $0.3 \mathrm{mg} / \mathrm{mL})$ and added to a Tris- $\mathrm{HCl}$ buffer (100 mM, pH 7.0) and $250 \mu \mathrm{M}$ DPPH dissolved in ethanol. The tubes were kept in the dark for $20 \mathrm{~min}$, and absorbance was measured at $517 \mathrm{~nm}$ (UV-1700 spectrophotometer, Shimadzu, Kyoto, Japan). The results are represented as $\mathrm{IC}_{50}$ (amount of extract necessary to scavenge $50 \%$ of the DPPH radical). To evaluate the antioxidant enzyme-like activities, the lyophilized powder was diluted at a concentration of $5 \%(\mathrm{w} / \mathrm{v})$. The superoxide dismutase (SOD)-like assay was conducted by measuring the inhibition of the rate of self-catalytic adrenochrome formation at $480 \mathrm{~nm}$, in a reaction medium containing $1 \mathrm{mmol} / \mathrm{L}$ adrenaline $(\mathrm{pH} 2.0)$ and $50 \mathrm{mmol} / \mathrm{L}$ glycine $(\mathrm{pH} \mathrm{10.2)}$. This reaction was performed at $30{ }^{\circ} \mathrm{C}$ for $3 \mathrm{~min}$ [14]. Results are expressed as $\mathrm{IC}_{50}$ ( $\mu \mathrm{L}$ from AAE needed to reduce the adrenochrome formation by $50 \%$ ). The catalase (CAT)-like assay was performed by determining the decomposition rate of hydrogen peroxide at $240 \mathrm{~nm}$ [15]. Results are expressed as $\mathrm{mmol}_{2} \mathrm{O}_{2}$ decomposed/minute. Catechin $(0.1 \%, \mathrm{w} / \mathrm{v})$ was used as a standard.

\subsection{MRC5 Cell Culture and Treatments}

MRC5 cells were cultivated under standard conditions in DMEM, supplemented with 10\% heat-inactivated FBS and 1\% penicillin-streptomycin. Cells were maintained in humidified atmosphere at $37{ }^{\circ} \mathrm{C}$ with $5 \% \mathrm{CO}_{2}$. Studies were conducted when the cells reached $70 \%-80 \%$ confluence. AAE was added to FBS-free medium to reach the non-cytotoxic concentrations of 25 and $50 \mu \mathrm{g} / \mathrm{mL}$, and incubated at $37{ }^{\circ} \mathrm{C}$ for $1 \mathrm{~h}$. After this, the oxidative challenge with $\mathrm{H}_{2} \mathrm{O}_{2}(900$ or $150 \mu \mathrm{M})$ was performed for $1 \mathrm{~h}$, in the dark, in FBS-free medium. For the comet assay (alkaline and enzymatic), the treatments were performed with $\mathrm{H}_{2} \mathrm{O}_{2}$ at $150 \mu \mathrm{M}$, because $900 \mu \mathrm{M}$ was very toxic to the DNA.

\subsection{Cellular Viability Assay}

Cell viability was measured using the MTT assay, which is based on the conversion of MTT to formazan crystals by mitochondrial dehydrogenases [16]. Cells were seeded into 96-well plates at a density of $1.0 \times 10^{5}$ cells $/ \mathrm{mL}$ in DMEM complete medium. After $24 \mathrm{~h}$, cells were treated with AAE and $\mathrm{H}_{2} \mathrm{O}_{2}(900 \mu \mathrm{M})$ and then incubated at $37{ }^{\circ} \mathrm{C}$ with $5 \% \mathrm{CO}_{2}$ for $1 \mathrm{~h}$. The medium was removed and $1 \mathrm{mg} / \mathrm{mL}$ MTT dye in serum-free medium was added to the wells. Plates were incubated at $37{ }^{\circ} \mathrm{C}$ for $3 \mathrm{~h}$. Subsequently, the MTT solution was removed and the obtained formazan violet product was dissolved in $100 \mu \mathrm{L}$ dimethylsulfoxide (DMSO), stirred for $15 \mathrm{~min}$ and the absorbance was measured using a microplate reader (Victor-X3, multilabel counter, Perkin Elmer, Finland) at $570 \mathrm{~nm}$. The absorbance of control cells was set as $100 \%$ viability and the valued of treated cells were calculated as percentage of control. 


\subsection{Determination of Oxidative Damage to Lipids and Proteins}

Oxidative damage to lipids and proteins was assessed in the cells after incubation with RIPA lysis buffer for $30 \mathrm{~min}$, and centrifugation at $1500 \times \mathrm{g}$ at $4{ }^{\circ} \mathrm{C}$ for $5 \mathrm{~min}$. The supernatant was used in both assays. Lipid damage was monitored by the formation of TBA reactive species (TBARS) during an acid-heating reaction, which has been widely adapted as a sensitive method for evaluating lipid peroxidation. Assays were performed according to Salgo and Pryor [17] with minor modifications. Briefly, $400 \mu \mathrm{L}$ of supernatant was combined with $600 \mu \mathrm{L}$ of $15 \%$ TCA and $0.67 \%$ TBA. The mixture was heated at $100{ }^{\circ} \mathrm{C}$ for $20 \mathrm{~min}$. After cooling to room temperature, the samples were centrifuged at $1300 \times \mathrm{g}$ for $10 \mathrm{~min}$. The supernatant was isolated, and its absorbance was measured at $532 \mathrm{~nm}$. TMP was used as a standard, and the results are expressed as nmol of TMP/mg of protein. Oxidative damage in proteins was measured by determining the carbonyl group based on the reaction with DNPH [18]. Two hundred $\mu \mathrm{L}$ of DNPH $(10 \mathrm{mM})$ or $200 \mu \mathrm{L}$ of $\mathrm{HCl}(2 \mathrm{M})$ for control were added to $50 \mu \mathrm{L}$ of supernatants. The reaction mixture was incubated in the dark for $30 \mathrm{~min}$, and vortexed every $10 \mathrm{~min}$. After, $250 \mu \mathrm{L}$ of $20 \%$ TCA were added and centrifuged at $1500 \times g$ for $8 \mathrm{~min}$. The supernatant was discarded and the pellet was washed 3 times with ethanol-ethyl acetate $(1: 1)$ to remove free reagent. Samples were centrifuged and pellets were redissolved in $1000 \mu \mathrm{L}$ of urea solution $(8 \mathrm{M})$ at $37^{\circ} \mathrm{C}$ for $15 \mathrm{~min}$. Absorbance was read at $365 \mathrm{~nm}$, and results are expressed as nmol DNPH/mg protein.

\subsection{Antioxidant Activity of Superoxide Dismutase and Catalase Enzymes}

After treatments, cells were incubated with lysis buffer (Tris-HCl $50 \mathrm{mM}, \mathrm{pH} 7.5$, EDTA $5 \mathrm{mM}$, dithiothreitol (DTT) $1 \mathrm{mM}$ ) for $30 \mathrm{~min}$, then scraped and centrifuged at $5000 \times \mathrm{g}$ at $4{ }^{\circ} \mathrm{C}$ for $15 \mathrm{~min}$. The supernatant was used in both assays. SOD activity was found by measuring the inhibition of self-catalytic adrenochrome formation rate at $480 \mathrm{~nm}$, in a reaction medium containing $1 \mathrm{mmol} / \mathrm{L}$ adrenaline $(\mathrm{pH} 2.0)$ and $50 \mathrm{mmol} / \mathrm{L}$ glycine $\left(\mathrm{pH}\right.$ 10.2). This reaction was performed at $30{ }^{\circ} \mathrm{C}$ for $3 \mathrm{~min}$ [14]. Results are expressed as USOD (units of enzyme activity)/mg protein. One unit is defined as the amount of enzyme that inhibits the rate of adrenochrome formation in $50 \%$. CAT activity was measured according to the methods described by Aebi [15]. The assay determines the rate of $\mathrm{H}_{2} \mathrm{O}_{2}$ decomposition at $240 \mathrm{~nm}$. The reaction was conducted at $30{ }^{\circ} \mathrm{C}$ for $1 \mathrm{~min}$. Results are expressed as $\mathrm{mmol} \mathrm{H} \mathrm{O}_{2} / \mathrm{min} / \mathrm{mg}$ protein. All absorbances were measured in spectrophotometer model UV-1700.

\subsection{Protein Content Determination}

Cell protein concentration was determined by the Lowry method using bovine serum albumin (BSA) as a standard, according to Lowry et al. [19].

\subsection{Antigenotoxicity Assay}

Single cell gel electrophoresis (comet assay) was performed as described by Singh et al. [20]. In addition, the enzymatic comet assay was carried out to assess DNA oxidative damage. For these assays, cells were washed with ice-cold PBS, trypsinized, and resuspended in a complete medium. Then, $20 \mu \mathrm{L}$ of cell suspension was dissolved in $0.75 \%$ low-melting point agarose and spread onto a glass microscope slide that was pre-coated with a layer of $1.5 \%$ normal melting point agarose. The 
slides were then incubated overnight in ice-cold lysis solution $(2.5 \mathrm{M} \mathrm{NaCl}, 10 \mathrm{mM}$ Tris, $100 \mathrm{mM}$ EDTA, $1 \%$ triton $\mathrm{X}-100$, and 10\% DMSO, $\mathrm{pH} 10.0$ ) to remove cellular proteins and membranes. In the enzymatic comet assay, the slides were removed from the lysing solution, washed 3 times in an enzyme buffer (40 mM HEPES, $100 \mathrm{mM} \mathrm{KCl,} 0.5 \mathrm{mM}$ EDTA, $0.2 \mathrm{mg} / \mathrm{mL} \mathrm{BSA}, \mathrm{pH} 8.0$ ) and incubated with $60 \mu \mathrm{L}$ of FPG $\left(100 \mathrm{~m}\right.$ Units per gel; $45 \mathrm{~min}$ at $\left.37^{\circ} \mathrm{C}\right)$ or Endo III $(100 \mathrm{~m}$ units per gel; $30 \mathrm{~min}$ at $37^{\circ} \mathrm{C}$ ). These enzymes recognize purine and pyrimidine oxidized bases, respectively [21]. Slides were placed on a horizontal electrophoresis unit and incubated in fresh buffer $(300 \mathrm{mM} \mathrm{NaOH}$, $1 \mathrm{mM}$ EDTA, pH 13). Enough buffer was used to cover the slides for $20 \mathrm{~min}$ at $4{ }^{\circ} \mathrm{C}$ and to allow for DNA unwinding and the expression of alkali-labile sites. Electrophoresis was conducted for 20 min at $25 \mathrm{~V}$ and $300 \mathrm{~mA}$. All of the above steps were performed in the dark to prevent additional DNA damage. Slides were then neutralized (0.4 M Tris, $\mathrm{pH}$ 7.5), stained with silver nitrate and analyzed with an optical microscope. Two hundred cells (100 cells from each of the two replicate slides) per concentration of each test were analyzed. Cells were visually scored according to tail length in five classes: (1) class 0: undamaged with no tail, (2) class 1: with tail shorter than the diameter of the head (nucleus), (3) class 2: with tail as long as 1-2 times the diameter of the head, (4) class 3: with tail more than 2 times the diameter of the head, and (5) class 4: comets with no heads. The damage index (DI) is an arbitrary score calculated for each sample, which ranges from 0 (no tail: 100 cells $\times 0$ ) to 400 (with maximum migration: 100 cells $\times 4$ ). In the enzymatic version of the comet assay, the damage index is the result of the subtraction of the DI of the alkaline assay of DI enzymatic assay. In both assays, the frequency $(\%)$ of the different classes of DNA damage was also evaluated.

\subsection{Statistical Analysis}

Results are expressed as mean \pm standard deviation obtained from three independent experiments. Statistical significance was evaluated using one-way analysis of variance (ANOVA) with post-hoc multiple comparisons procedure (Tukey's test). The relationships between the variables were assessed with Pearson's product-moment correlation coefficient. Significance was accepted at $P$ lower than 0.05 or 0.01. The Statistical Package for Social Sciences (SPSS, version 19.0, Armonk, NY, USA) for Windows was used for analysis.

\section{Results and Discussion}

Bioactive compounds found in plants have gained attention mainly because of their healthy benefits. Brazil is rich in biodiversity and presents six main biomes, including the Atlantic Forest biome in the south of the country. In this biome, the A. angustifolia is the main native species. In this study, we investigated chemical and biological effects of $A$. angustifolia bracts, a non-edible part of the plant. The results showed that AAE presents high levels of phenolic compounds $(1586 \pm 14.53 \mathrm{mg}$ GAE/100 $\mathrm{g}$ of bracts). This data is in agreement with the results found for cooked seeds of A. angustifolia [22]. The polyphenol content of AAE was higher than that reported for other rich phenolic products, such as red wine $(200.40 \mathrm{mg} / 100 \mathrm{~mL})$ [23], fresh plums (366 mg/100 g) [24], and blackberries (486.53 mg/100 g) [25], showing that AAE could be a good source of polyphenols.

HPLC analysis (Figure 1) demonstrated that the major compounds of the extract were catechin $(140.6 \pm 2.86 \mathrm{mg} / 100 \mathrm{~g}$ bracts), epicatechin $(41.3 \pm 2.73 \mathrm{mg} / 100 \mathrm{~g}$ bracts $)$, quercetin $(23.2 \pm 0.06 \mathrm{mg} / 100 \mathrm{~g}$ 
bracts) and apigenin $(0.6 \pm 0.06 \mathrm{mg} / 100 \mathrm{~g}$ bracts $)$, being these last two compounds identified for the first time in $A$. angustifolia bracts.

Figure 1. Chromatograms (HPLC) for flavonoids (A) at $350 \mathrm{~nm}$ and tannins (B) at $280 \mathrm{~nm}$ of $A$. angustifolia aqueous extract.

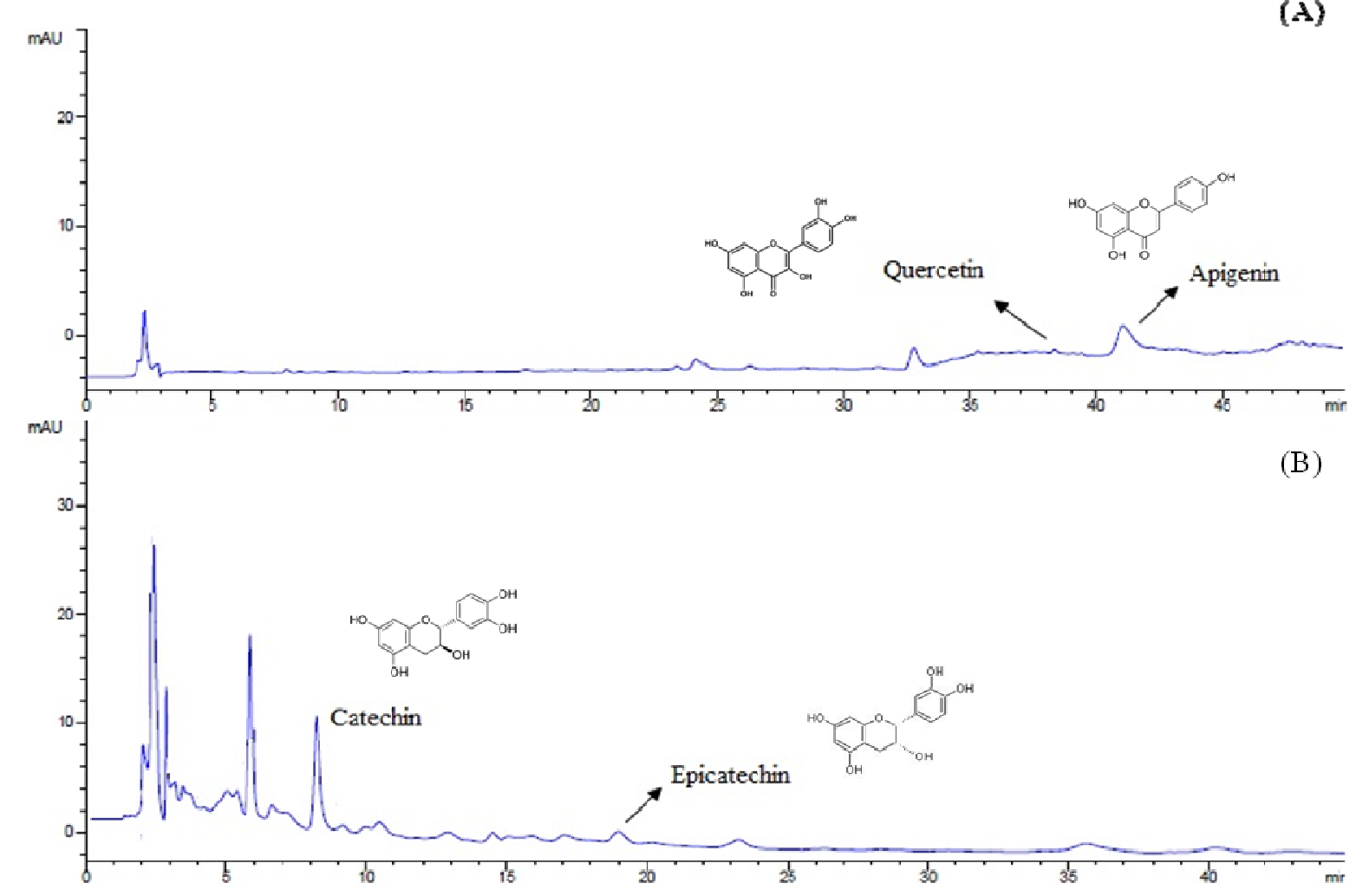

Polyphenols are secondary metabolites characterized by the presence of two or more phenol units. According to their chemical structure, polyphenols can be divided in flavonoids and non-flavonoids [26]. Flavonoids are the most important group and present beneficial effects in cancer, cardiovascular and neurodegenerative diseases [27,28]. In general, high phenol content correlates with high antioxidant activity. Due to the presence of high amounts of polyphenols in the AAE, we evaluated the ability of the extract to scavenge the stable DPPH radical. Additionally, the capability of AAE to act as the antioxidant enzymes SOD and CAT was evaluated. SOD catalyzes the dismutation of superoxide by the production of $\mathrm{H}_{2} \mathrm{O}_{2}$, which can be eliminated by the action of catalase [29]. A. angustifolia extract showed important radical scavenging activity ( $\mathrm{IC}_{50}: 0.146 \pm 0.14 \mathrm{mg} / \mathrm{mL}$ ), measured by DPPH method. Moreover, SOD- and CAT-like activities were higher than those presented by standard catechin (Table 1). This indicates that AAE is able to reduce the DPPH radical and scavenge the superoxide anion and $\mathrm{H}_{2} \mathrm{O}_{2}$, two RS that can damage cells. Polyphenols such as catechin and quercetin have previously been reported to scavenge the superoxide radical and $\mathrm{H}_{2} \mathrm{O}_{2}$ [30,31]. The ability of AAE to act as an antioxidant enzyme plays an important role in maintaining the redox balance of the cells. 
Table 1. In vitro antioxidant activity of the Araucaria angustifolia extract (AAE).

\begin{tabular}{|c|c|c|c|}
\hline Samples & $\begin{array}{c}\text { DPPH } \\
\left(\mathrm{IC}_{50}\right)^{\#} \\
\end{array}$ & $\begin{array}{c}\text { SOD-like activity } \\
\left(\mathrm{IC}_{\mathbf{5 0}}\right)^{\S}\end{array}$ & $\begin{array}{l}\text { CAT-like activity } \\
\left(\mathrm{mmol} \mathrm{H}_{2} \mathrm{O}_{2} / \mathrm{min}\right)\end{array}$ \\
\hline AAE & $0.146 \pm 0.14^{\mathrm{a}, *}$ & $5.73 \pm 1.40^{\mathrm{a}}$ & $225.00 \pm 43.30^{\mathrm{a}}$ \\
\hline Catechin & $0.104 \pm 0.01^{\mathrm{b}}$ & $13.53 \pm 0.037^{\mathrm{b}}$ & $7.50 \pm 0.02^{b}$ \\
\hline
\end{tabular}

To study the effect of AAE in mammalian cells, MRC5 cells were treated with AAE and challenged with $\mathrm{H}_{2} \mathrm{O}_{2}$. The results showed that the non-cytotoxic concentrations of AAE ( 25 and $50 \mu \mathrm{g} / \mathrm{mL}$ ) were able to reduce $(25 \mu \mathrm{g} / \mathrm{mL})$ or completely avoid $(50 \mu \mathrm{g} / \mathrm{mL})$ the mortality induced by $\mathrm{H}_{2} \mathrm{O}_{2}$ (Figure 2). In addition, AAE minimizes $(25 \mu \mathrm{g} / \mathrm{mL})$ or avoids $(50 \mu \mathrm{g} / \mathrm{mL})$ oxidative lipid and protein damage induced by $\mathrm{H}_{2} \mathrm{O}_{2}$. AAE also diminished $(25 \mu \mathrm{g} / \mathrm{mL})$ or avoided $(50 \mu \mathrm{g} / \mathrm{mL})$ the SOD and CAT depletion observed after $\mathrm{H}_{2} \mathrm{O}_{2}$ treatment (Table 2). $\mathrm{H}_{2} \mathrm{O}_{2}$ is generated from a variety of sources under oxidative stress and can diffuse freely in and out of cells and tissues [32] inducing cell damage. Several biomolecules can be damaged under oxidative stress and lipids are easy targets for RS. Proteins can also be damaged. The oxidation of cell membranes and amino acid side chains may lead to a loss of cell integrity and cell death [33]. To counteract RS, antioxidant enzymes, such as SOD and CAT, are the first line of defense against oxidative injury [29]. In this study, it was shown that AAE significantly protected MRC5 cells against the $\mathrm{H}_{2} \mathrm{O}_{2}$-induced mortality. This effect was accomplished by a reduction in oxidative damage to lipids, oxidative damage to proteins, and depletion of SOD and CAT activities induced by $\mathrm{H}_{2} \mathrm{O}_{2}$. These data corroborate models of similar studies, where treatment with polyphenols inhibited lipid oxidation and the decrease in SOD and CAT activities induced by $\mathrm{H}_{2} \mathrm{O}_{2}[34,35]$.

Figure 2. Cell viability of human lung fibroblast cells (MRC5). MRC5 cells were treated for $1 \mathrm{~h}$ with Araucaria angustifolia extract (AAE) in FBS-free medium and subsequently administered $\mathrm{H}_{2} \mathrm{O}_{2}(900 \mu \mathrm{M})$ for $1 \mathrm{~h}$. Data are mean $\pm \mathrm{SD}$ values. ${ }^{*}$ Different letters indicate significant difference according to analysis of variance (ANOVA) and Tukey's post-hoc test $(p \leq 0.05)$.

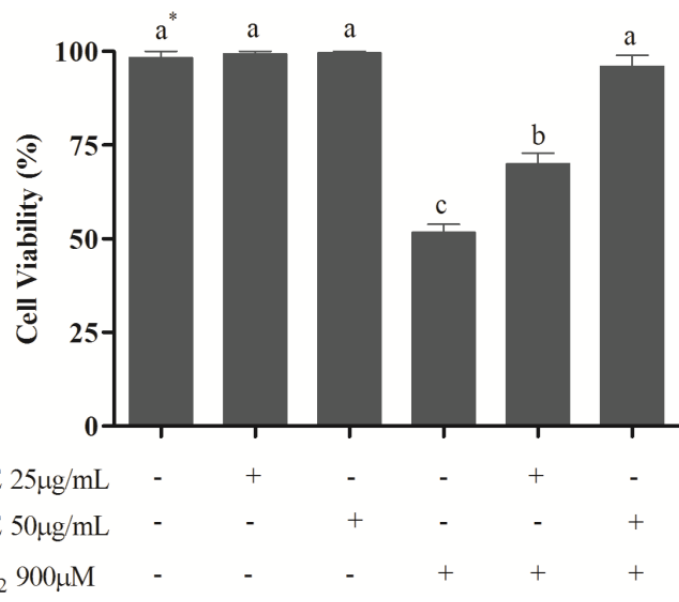


Table 2. Determination of the thiobarbituric acid reactive substances (TBARS), carbonyl protein, superoxide dismutase (SOD), and catalase (CAT) activities in the MRC5 cells pretreated with the extract of bracts of $A$. angustifolia and $\mathrm{H}_{2} \mathrm{O}_{2}$.

\begin{tabular}{ccccc}
\hline Treatments & $\begin{array}{c}\text { TBARS } \\
\text { (nmol TMP/mg } \\
\text { of protein) }\end{array}$ & $\begin{array}{c}\text { Carbonyl } \\
\text { protein } \\
\text { (nmol DNPH/mg } \\
\text { of protein) }\end{array}$ & $\begin{array}{c}\text { SOD } \\
\text { (U SOD/mg } \\
\text { of protein) }\end{array}$ & $\begin{array}{c}\text { CAT (mmol } \\
\mathbf{H}_{2} \mathbf{O}_{2} / \mathbf{m i n} / \mathbf{m g} \\
\text { of protein) }\end{array}$ \\
\hline Cell Control & $0.57 \pm 0.08^{\mathrm{a}}$ & $1.85 \pm 0.08^{\mathrm{a}}$ & $19.40 \pm 0.49^{\mathrm{b}}$ & $15.19 \pm 0.56^{\mathrm{a}}$ \\
$\mathrm{H}_{2} \mathrm{O}_{2} 900 \mu \mathrm{M}$ & $2.21 \pm 0.06^{\mathrm{c}}$ & $4.51 \pm 0.15^{\mathrm{c}}$ & $9.32 \pm 0.13^{\mathrm{d}}$ & $9.75 \pm 0.08^{\mathrm{c}}$ \\
$\mathrm{AAE} 25 \mu \mathrm{g} / \mathrm{mL}$ & $0.54 \pm 0.01^{\mathrm{a}}$ & $1.94 \pm 0.10^{\mathrm{a}}$ & $19.00 \pm 0.34^{\mathrm{b}}$ & $14.25 \pm 0.65^{\mathrm{a}}$ \\
$\mathrm{AAE} 50 \mu \mathrm{g} / \mathrm{mL}$ & $0.51 \pm 0.15^{\mathrm{a}}$ & $1.88 \pm 0.06^{\mathrm{a}}$ & $23.81 \pm 0.01^{\mathrm{a}}$ & $14.63 \pm 0.06^{\mathrm{a}}$ \\
$\mathrm{AAE} 25 \mu \mathrm{g} / \mathrm{mL}+\mathrm{H}_{2} \mathrm{O}_{2}$ & $0.86 \pm 0.03^{\mathrm{b}}$ & $3.09 \pm 0.51^{\mathrm{b}}$ & $13.46 \pm 0.02^{\mathrm{c}}$ & $12.38 \pm 0.01^{\mathrm{b}}$ \\
$\mathrm{AAE} 50 \mu \mathrm{g} / \mathrm{mL}+\mathrm{H}_{2} \mathrm{O}_{2}$ & $0.52 \pm 0.16^{\mathrm{a}}$ & $2.24 \pm 0.16^{\mathrm{a}}$ & $19.51 \pm 0.22^{\mathrm{b}}$ & $14.07 \pm 0.05^{\mathrm{a}}$ \\
\hline Data are mean $\pm \mathrm{SD}$ values. Different letters indicate significant differences according to analysis of variance \\
(ANOVA) and Tukey's post-hoc test $(p \leq 0.05)$ in each assay.
\end{tabular}

Many methods are currently used for detecting the biological effects of DNA-damaging agents. The single cell gel electrophoresis or comet assay has been shown to be a sensitive method for investigating DNA damage. The alkaline version of this assay detects DNA strand breaks, alkali-labile sites, DNA crosslinking, and incomplete excision repair [20,21]. To verify if DNA damage is due to oxidative lesions, it is possible to use the enzymatic version of the test, performed with Endo III and FPG [21].

According to the alkaline comet assay, AAE alone did not cause DNA damage in MRC5 in the studied concentrations (Figure 3A). Additionally, the extract ( 25 and $50 \mu \mathrm{g} / \mathrm{mL}$ ) was able to reduce DNA damage induced by $\mathrm{H}_{2} \mathrm{O}_{2}$ by $30 \%$ and $56 \%$, respectively (Figure $3 \mathrm{~A}$ ). $\mathrm{H}_{2} \mathrm{O}_{2}$ administration induces high levels of genotoxicity, increasing the frequency of classes 2, 3, and 4 of DNA damage. This damage was reduced by AAE treatment (Figure 3B). The enzymes Endo III and FPG allowed the evaluation of DNA base oxidation. AAE reduced the oxidative damage recognized by repair protein Endo III by $21 \%(25 \mu \mathrm{g} / \mathrm{mL})$ and $44 \%(50 \mu \mathrm{g} / \mathrm{mL})$. AAE was also able to minimize the oxidative damage recognized by the repair FPG protein by $38 \%(25 \mu \mathrm{g} / \mathrm{mL})$ and $60 \%(50 \mu \mathrm{g} / \mathrm{mL})$ (Figure $4 \mathrm{~A})$. As observed in the alkaline comet assay, AAE treatment reduced the frequency of classes 2, 3, and 4 of DNA damage (Figure 4B). The antigenotoxic effect of AAE could be important to preventing the DNA damage associated with carcinogenesis.

Correlation analysis showed a strong negative relationship between lipid, protein, and DNA damage with SOD and CAT activities (Table 3). In addition, a strong positive correlation was found between cell viability and SOD and CAT activities, suggesting a critical detoxification by these antioxidant enzymes with a cytoprotective effect. This data suggests that SOD and CAT play an important role against lipid, protein, and DNA damage, apparently through a concerted effort that includes the dismutation of superoxide, inactivation of $\mathrm{H}_{2} \mathrm{O}_{2}$, and maintenance of a cellular reducing environment. 
Figure 3. (A) DNA damage index by the alkaline Comet assay in MRC5 cells after treatment with $\mathrm{AAE}$ and exposure to $\mathrm{H}_{2} \mathrm{O}_{2}$. * Different letters indicate significant differences by analysis of variance (ANOVA) and Tukey's post-hoc test $(p \leq 0.05)$. (B) Frequency (\%) of different classes of DNA damage in control and AAE-treated groups. The cells were assessed visually and received scores from 0 (no injury) to 4 (maximally damaged), according to the size and shape of the tail. Data are mean \pm SD values.

(A)

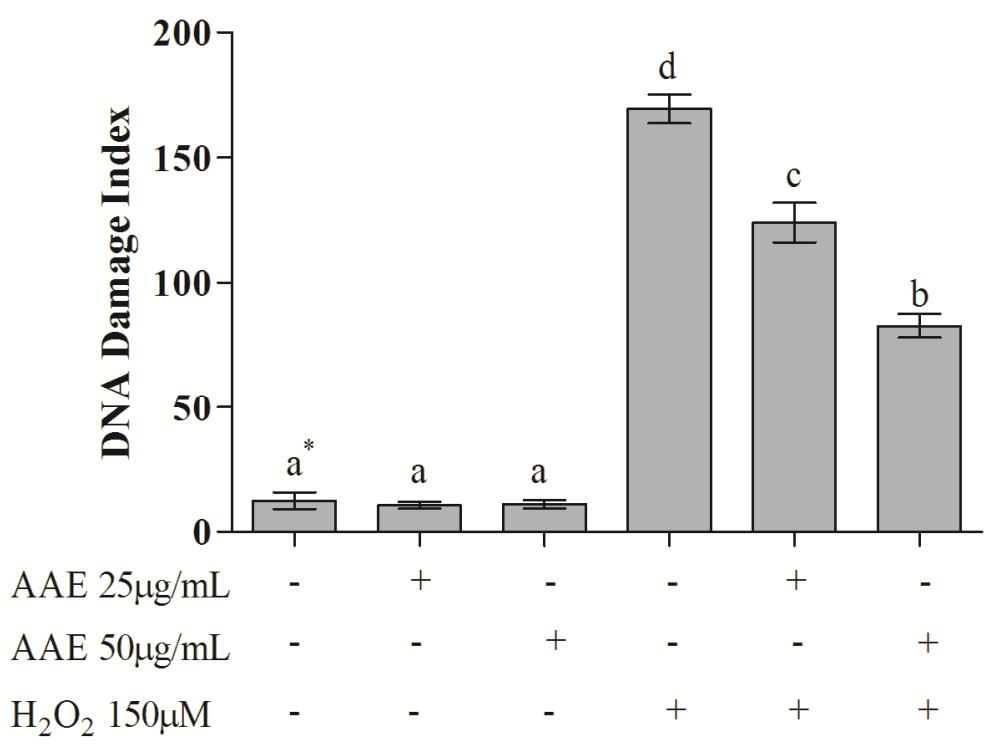

(B)

\begin{tabular}{|c|c|c|c|c|c|}
\hline & $\begin{array}{c}\text { Und amaged } \\
\text { cell }\end{array}$ & Class one & Class two & Class three & Class fou r \\
\hline Cell control & $94.00 \pm 2.65$ & $5.00 \pm 1.00$ & $2.00 \pm 0.58$ & $1.00 \pm 0.50$ & $0.00 \pm 0.00$ \\
\hline $\mathrm{H}_{2} \mathrm{O}_{2} 150 \mu \mathrm{M}$ & $24.00 \pm 1.15$ & $22.00 \pm 1.15$ & $27.0 \pm 1.00$ & $32.00 \pm 1.73$ & $3.00 \pm 0.58$ \\
\hline $\mathrm{AAE} 25 \mu \mathrm{g} / \mathrm{mL}+\mathrm{H}_{2} \mathrm{O}_{2}$ & $18.00 \pm 1.73$ & $57.00 \pm 2.89$ & $14.00 \pm 0.58$ & $17.00 \pm 1.53$ & $0.00 \pm 0.00$ \\
\hline $\mathrm{AAE} 50 \mu \mathrm{g} / \mathrm{mL}+\mathrm{H}_{2} \mathrm{O}_{2}$ & $36.00 \pm 2.52$ & $52.00 \pm 0.58$ & $14.00 \pm 1.15$ & $2.00 \pm 0.60$ & $0.00 \pm 0.00$ \\
\hline
\end{tabular}

Table 3. Pearson correlations between cellular antioxidant enzymes activities, lipid and protein oxidative damage, DNA damage index, and cell viability assays.

\begin{tabular}{cccccc}
\hline Assays & SOD & CAT & TBARS & $\begin{array}{c}\text { Carbonyl } \\
\text { protein }\end{array}$ & $\begin{array}{c}\text { DNA } \\
\text { damage }\end{array}$ \\
\hline TBARS & $-0.866 *$ & $-0.945 * *$ & - & $0.959 * *$ & $0.816 *$ \\
Carbonyl protein & $-0.933 * *$ & $-0.992 * *$ & $0.959 * *$ & - & $0.940 * *$ \\
DNA damage & $-0.892 *$ & $-0.933 * *$ & $0.816 *$ & $0.940 * *$ & - \\
Cell viability & $0.943 * *$ & $0.977 * *$ & $-0.923 * *$ & $-0.985 * *$ & $-0.927 * *$ \\
\hline
\end{tabular}

Statistically significant $*$ for $p \leq 0.05$ and $* *$ for $p \leq 0.01$. 
Figure 4. (A) Content of DNA damage oxidative by the Comet assay modified. * Different letters indicate significant differences by analysis of variance (ANOVA) and Tukey's post-hoc test $(p \leq 0.05)$. (B) Frequency (\%) of different classes of DNA damage (Comet assay). Cells were evaluated visually and were given scores of 0 (no injury) to 4 (maximally damaged) according to the size and shape of the tail. Data are mean \pm SD values.

(A)

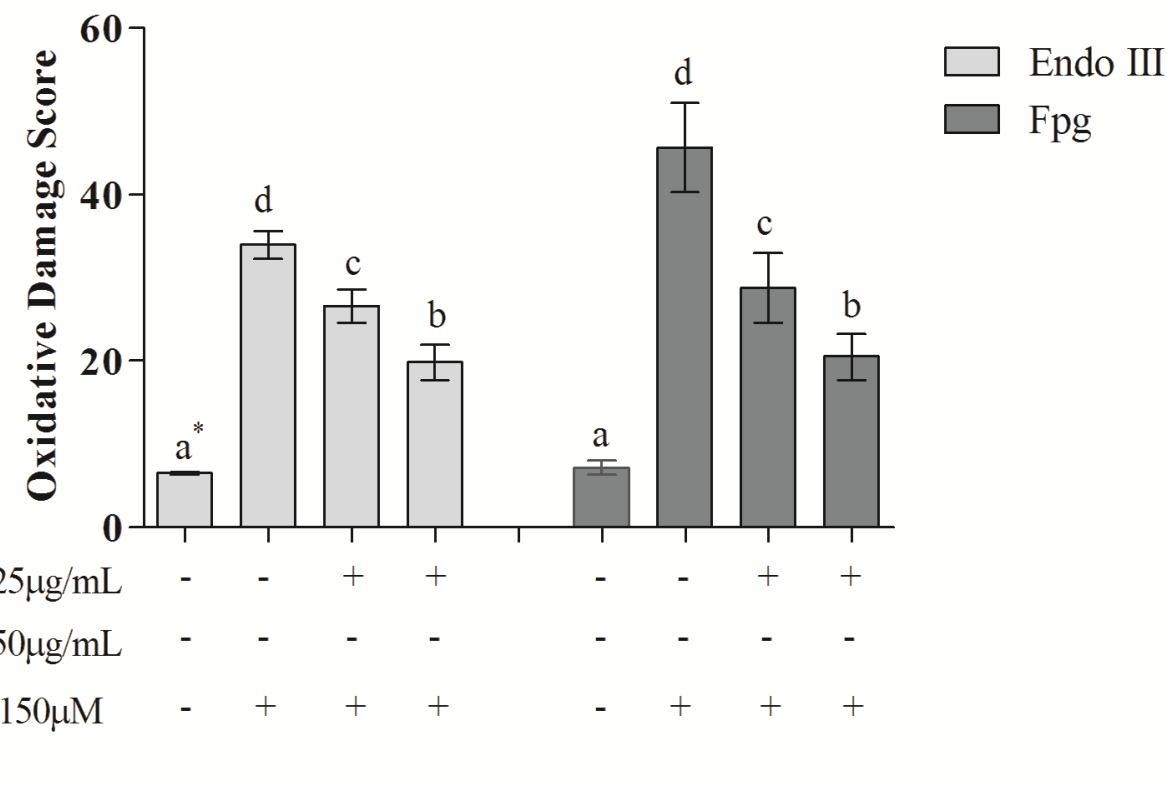

(B)

AAE $25 \mu \mathrm{g} / \mathrm{mL}$

AAE $50 \mu \mathrm{g} / \mathrm{mL}$

$\mathrm{H}_{2} \mathrm{O}_{2} 150 \mu \mathrm{M}$

Undamaged

cell

Class one Class two Class three Class four

\begin{tabular}{|c|c|c|c|c|c|}
\hline \multicolumn{6}{|c|}{ En do III } \\
\hline Cell control & $89.00 \pm 1.00$ & $8.00 \pm 1.15$ & $2.00 \pm 1.20$ & $0.00 \pm 0.00$ & $0.00 \pm 0.00$ \\
\hline $\mathrm{H}_{2} \mathrm{O}_{2} 150 \mu \mathrm{M}$ & $8.00 \pm 0.58$ & $22.00 \pm 0.60$ & $31.0 \pm 1.00$ & $39.00 \pm 1.00$ & $4.00 \pm 0.50$ \\
\hline AAE $25 \mu \mathrm{g} / \mathrm{mL}+\mathrm{H}_{2} \mathrm{O}_{2}$ & $3.00 \pm 1.15$ & $43.00 \pm 1.00$ & $49.00 \pm 2.08$ & $5.00 \pm 0.82$ & $1.00 \pm 0.01$ \\
\hline AAE $50 \mu \mathrm{g} / \mathrm{mL}+\mathbf{H}_{2} \mathbf{O}_{2}$ & $20.50 \pm 0.71$ & $51.00 \pm 1.20$ & $24.00 \pm 1.15$ & $1.00 \pm 0.01$ & $0.00 \pm 0.00$ \\
\hline \multicolumn{6}{|c|}{ Fpg } \\
\hline Cell control & $88.50 \pm 1.41$ & $9.50 \pm 1.89$ & $2.00 \pm 0.55$ & $1.00 \pm 0.01$ & $0.00 \pm 0.00$ \\
\hline $\mathrm{H}_{2} \mathrm{O}_{2} 150 \mu \mathrm{M}$ & $8.00 \pm 0.60$ & $17.50 \pm 0.96$ & $30.5 \pm 1.00$ & $38.00 \pm 1.30$ & $7.50 \pm 0.58$ \\
\hline AAE $25 \mu \mathrm{g} / \mathrm{mL}+\mathrm{H}_{2} \mathrm{O}_{2}$ & $3.00 \pm 1.15$ & $42.00 \pm 1.50$ & $50.00 \pm 1.15$ & $5.00 \pm 0.58$ & $1.00 \pm 0.01$ \\
\hline $\mathrm{AAE} 50 \mu \mathrm{g} / \mathrm{mL}+\mathrm{H}_{2} \mathrm{O}_{2}$ & $30.00 \pm 1.53$ & $45.00 \pm 1.73$ & $25.00 \pm 1.15$ & $1.00 \pm 0.01$ & $0.00 \pm 0.00$ \\
\hline
\end{tabular}

It is possible that phenolic compounds found in AAE could be responsible for the important antioxidant and antigenotoxic effects observed in this study, as already reported for this [9] and other plants [36-38]. However, no statistically significant correlations were found between the amount of polyphenols and the prevention of oxidative damage. This may be because we analyzed only two close concentrations ( 25 and $50 \mu \mathrm{g} / \mathrm{mL}$ ) of the AAE. Assays with a wide range of concentrations as well as 
the evaluation of the isolated polyphenols could be helpful to identify the molecules that are responsible for the biological effects of AAE.

\section{Conclusions}

We found that AAE has an important protective effect against oxidative damage of lipids, proteins, and DNA in human lung fibroblast cells. Moreover, this extract is rich in polyphenols and is a good source of antioxidant natural compounds, mainly catechin, epicatechin, quercetin and apigenin, which present great importance in inhibiting oxidative mechanisms associate to degenerative diseases and cancer. The properties presented by the A. angustifolia can be used to explore new resources for pharmacological structures and/or to improve natural medicine.

\section{Acknowledgments}

This work was supported by the Conselho Nacional de Desenvolvimento Científico e Tecnológico (CNPq), Fundação de Amparo à Pesquisa do Estado do Rio Grande do Sul (FAPERGS), and the Coordenação de Apoio de Pessoal de Nível Superior (CAPES).

\section{Conflicts of Interest}

The authors declare no conflict of interest.

\section{References}

1. Franco, I.J.; Fontana, V.L. Ervas \& Plantas: A Medicina dos Simples; Imprimax: Erechim, Brazil, 1997; p. 177.

2. Marquesini, N.R. Medicinal Plants Used by the Indians as the Parana and Santa Catarina, Southern Brazil: Guarani, Kaingang, Xokleng, Ava-Guarani, Kraô e Cayuá. Master's Thesis, University Federal do Paraná, Curitiba, Brazil, 1995.

3. Seccon, A.; Rosa, D.W.; Freitas, R.A.; Biavatti, M.W.; Creczynsky-Pasa, T.B. Antioxidant activity and low cytotoxicity of extracts and isolated compounds from Araucaria angustifolia dead bark. Redox Rep. 2010, 15, 1-8.

4. Yamaguchi, L.F.; Giddings, D.V.; Kato, M.J.; Di Mascio, P. Biflavonoids from Brazilian pine Araucaria angustifolia as potential protective agents against DNA damage and lipoperoxidation. Phytochemistry 2005, 66, 2238-2247.

5. Yamaguchi, L.F.; Kato, M.J.; Di Mascio, P. Biflavonoids from Araucaria angustifolia protect against DNA UV-induced damage. Phytochemistry 2009, 70, 615-620.

6. Freitas, A.M.; Almeida, M.T.R.; Andrighetti-Fröhner, C.R.; Cardozo, F.T.G.S.; Barardi, C.R.M.; Farias, M.R.; Simões, C.M.O. Antiviral activity-guided fractionation from Araucaria angustifolia leaves extract. J. Ethnopharmacol. 2009, 126, 512-517.

7. Yamamoto, S.; Otto, A.; Simoneit, B.R.T. Lignans in resin of Araucaria angustifolia by gas chromatography/mass spectrometry. J. Mass Spectrom. 2004, 39, 1337-1347. 
8. Santi-Gadelha, T.; Gadelha, C.A.A.; Aragão, K.S.; Oliveira, C.C.; Mota, M.R.L.; Gomes, R.C.; Pires, A.F.; Toyama, M.H.; Toyama, D.O.; Alencar, N.M.; et al. Purification and biological effects of Araucaria angustifolia (Araucariaceae) seed lectin. Biochem. Biophys. Res. Commun. 2006, 350, 1050-1055.

9. Michelon, F.; Branco, C.S.; Calloni, C.; Giazzon, I.; Agostini, F.; Spada, P.K.W.; Salvador, M. Araucaria Angustifolia: A potential nutraceutical with antioxidant and antimutagenic activities. Curr. Nutr. Food Sci. 2012, 8, 155-159.

10. Branco, C.S.; Scola, G.; Rodrigues, A.; Cesio, V.; Heinzen, H.; Godoy, A.; Funchal, C.; Coitinho, A.; Salvador, M. Organic and conventional yerba mate (Ilex paraguariensis A. St. Hil) improves metabolic redox status of liver and serum in Wistar rats. Antioxidants 2013, 2, 100-109.

11. Halliwell, B. Dietary polyphenols: Good, bad, or indifferent for your health? Cardiovasc. Res. 2007, 73, 341-347.

12. Singleton, V.L.; Orthofer, R.; Lamuela-Raventós, R.M. Analysis of Total Phenols and Other Oxidation Substrates and Antioxidants by Means of Folin-Ciocalteu Reagent. In Methods in Enzymology, Oxidant and Antioxidant (Part A); Packer, L., Ed.; Academic Press: San Diego, CA, USA, 1999; pp. 152-178.

13. Yamaguchi, T.; Takamura, M.; Matoba, T.; Terao, J. HPLC method for evaluation of the free radical-scavenging of foods by using 1,1-diphenyl-2-pycrylhidrazyl. Biosci. Biotechnol. Biochem. 1998, 62, 1201-1204.

14. Bannister, J.V.; Calabrese, L. Assays for SOD. Methods Biochem. Anal. 1987, 32, 279-312.

15. Aebi, H. Catalase in vitro. Methods Enzymol. 1984, 105, 121-126.

16. Denizot, F.; Lang, R. Rapid colorimetric assay for cell growth and survival. Modifications to the tetrazolium dye procedure giving improved sensitivity and reliability. J. Immunol. Methods 1986, 2, 271-277.

17. Salgo, M.G.; Pryor, W.A. Trolox inhibits peroxynitrite-mediated oxidative stress and apoptosis in rat thymocytes. Arch. Biochem. Biophys. 1996, 333, 482-488.

18. Levine, R.L.; Garland, D.; Oliver, C.N.; Amici, A.; Climent, I.; Lenz, A.G.; Ahn, B.W.; Stadtman, E.R. Determination of carbonyl content in oxidatively modified proteins. Methods Enzymol. 1990, 186, 464-478.

19. Lowry, O.H.; Rosebrough, N.J.; Farr, L.; Randall, R.J. Protein measurement with the Folin phenol reagent. J. Biol. Chem. 1951, 193, 265-275.

20. Singh, N.P.; McCoy, M.T.; Tice, R.; Scheneider, E.L. A simple technique for quantification of low levels of DNA damage in individual cells. Exp. Cell Res. 1988, 175, 184-191.

21. Collins, A.R.; Oscoz, A.A.; Brunborg, G.; Gaivão, I.; Giovannelli, L.; Kruszewski, M.; Smith, C.C.; Stetina, R. The comet assay: Topical issues. Mutagenesis 2008, 23, 143-151.

22. Koehnlein, E.A.; Carvajal, A.E.S.; Koehnlein, E.M.; Coelho-Moreira, J.S.; Inácio, F.D.; Castoldi, R.; Bracht, A.; Peralta, R.M. Antioxidant activities and phenolic compounds of raw and cooked Brazilian pinhão (Araucaria angustifolia) seeds. Afr. J. Food Sci. 2012, 6, 512-518.

23. Lopez, M.; Martinez, F.; Del Valle, C.; Orte, C.; Miro, M. Analysis of phenolic constituents of biological interest in red wines by high-performance liquid chromatography. J. Chromatogr. A 2001, 922, 359-363. 
24. Wu, X.; Beecher, G.R.; Holden, J.M.; Haytowitz, D.B.; Gebhardt, S.E.; Prior, R.L. Lipophilic and hydrophilic antioxidant capacities of common foods in the United States. J. Agric. Food Chem. 2004, 52, 4026-4037.

25. Sellappan, S.; Akoh, C.C.; Krewer, G. Phenolic compounds and antioxidant capacity of Georgia-Grown Blueberries and Blackberries. J. Agric. Food Chem. 2002, 50, 2432-2438.

26. Del Rio, D.; Rodriguez-Mateos, A.; Spencer, J.P.E.; Tognolini, M.; Borges, G.; Crozier, A. Dietary (Poly)phenolics in human health: Structures, bioavailability, and evidence of protective effects. Antioxid. Redox Signal. 2013, 18, 1818-1892.

27. Asensi, M.; Ortega, A.; Mena, S.; Feddi, F.; Estrela, J.M. Natural polyphenols in cancer therapy. Crit. Rev. Clin. Lab. Sci. 2011, 48, 197-216.

28. Obrenovich, M.E.; Li, Y.; Parvathaneni, K.; Yendluri, B.B.; Palacios, H.H.; Leszek, J.; Aliev, G. Antioxidants in health, disease and aging. CNS Neurol. Disord. Drug Targets 2011, 10, 192-207.

29. Halliwell, B.; Gutteridge, J.M.C. Free Radicals in Biology and Medicine, 4th ed.; Oxford University Press: Oxford, UK and New York, NY, USA, 2007.

30. Dias, A.S.; Lima, A.C.; Santos, A.L.; Rabelo, T.K.; Serafini, M.R.; Andrade, C.R.; Fernandes, X.A.; Moreira, J.C.; Gelain, D.P.; Estevam, C.S.; et al. Redox properties of Abarema cochliacarpos (Gomes) Barneby \& Grime (Fabaceae) stem bark ethanol extract and fractions. Nat. Prod. Res. 2012, 27, 1479-1483.

31. Farrar, J.L.; Hartle, D.K.; Hargrove, J.L.; Greenspan, P. Inhibition of protein glycation by skins and seeds of the muscadine grape. Biofactors 2007, 30, 193-200.

32. Halliwell, B. Free radicals and antioxidants: A personal view. Nutr. Rev. 1994, 52, 253-265.

33. Butterfield, D.A.; Castenga, A.; Pocernich, C.B.; Drake, J.; Scapagnini, G.; Calabrese, V. Nutritional approaches to combat oxidative stress in Alzheimer's disease. J. Nutr. Biochem. 2002, 13, 444-461.

34. Feng, B.; Fang, Y.; Wei, S.M. Effect and mechanism of epigallocatechin-3-gallate (EGCG) against the hydrogen peroxide-induced oxidative damage in human dermal fibroblasts. J. Cosmet. Sci. 2013, 64, 35-44.

35. Cumaoglu, A.; Rackova, L.; Stefek, M.; Kartal, M.; Maechler, P.; Karasu, C. Effects of olive leaf polyphenols against $\mathrm{H}_{2} \mathrm{O}_{2}$ toxicity in insulin secreting $\beta$-cells. Acta Biochem. Pol. 2011, 58, 45-50.

36. Chies, C.E.; Branco, C.S.; Scola, G.; Agostini, F.; Gower, A.E.; Salvador, M. Antioxidant effect of Lippia alba (Miller) N. E. Brown. Antioxidants 2013, 2, 194-205.

37. Chaabane, F.; Boubaker, J.; Loussaif, A.; Aicha, N.; Kilani-Jaziri, S.G.; Chekir-Ghedira, L. Antioxidant, genotoxic and antigenotoxic activities of daphne gnidium leaf extracts. $B M C$ Complement. Altern. Med. 2012, 12, 153.

38. Dassprakash, M.V.; Arun, R.; Abraham, S.K.; Premkumar, K. In vitro and in vivo evaluation of antioxidant and antigenotoxic potential of Punica granatum leaf extract. Pharm. Biol. 2012, 50, $1523-1530$.

(C) 2014 by the authors; licensee MDPI, Basel, Switzerland. This article is an open access article distributed under the terms and conditions of the Creative Commons Attribution license (http://creativecommons.org/licenses/by/3.0/). 